\title{
ELT DURING COVID-19 PANDEMIC; PRACTICES AND CHALLENGES
}

\author{
Ahmad Syafi'i \\ ahmadsyafii20@gmail.com \\ English Language Department, STKIP Al Hikmah Surabaya
}

\begin{abstract}
The purpose of this study is to evaluate the practices and challenges of online learning or so called Learning From Home (LFH) in English Department during the even semester 2019/2020 academic year. The subject of this study are 8 lecturers of English Department at STKIP Al Hikmah. This study employed descriptive qualitative research design. The instrument used is daily online teaching monitoring and evaluation questionnaire. The result of this study is categorized into five aspects namely 1) online learning applications frequently used by the lecturers are WhatsApp, Google Classroom, Schoology, Quizizz, E-mail, Zoom Cloud Meeting, Email, and Youtube 2) online learning activities frequently conducted by the lecturers are uploading materials, discussion forum, conducting quizzes, uploading assigment, and video conferences, 3) scheduled assignment submission rate, 4) students' participation rate and 5) challenges and alternative solution proposed by the lecturers during the online learning.
\end{abstract}

Keywords: ELT, practices, challenges, Covid-19 Pandemic

\section{INTRODUCTION}

The Covid-19 epidemic has seriously changed the teaching and learning framework and practice amongst all educational levels. Traditional face-to-face classrooms have been changed to distance classes because of medical conditions. It then permits schools or colleges to upgrade IT-based teaching and learning practices (Allo, 2020). It is compatible with the policy of the Ministry of Education and Culture that educational institutions, including higher education, were already instructed to reinvent traditional learning or so-called "personal" online learning for a temporary period of time (Irfan et al., 2020). He added that, regardless of strengths and weaknesses, on-line learning is one of the most successful alternatives. He said that online learning in terms of time and place is more practical.

Online learning is used to refer to web-based training, e-learning, distributed learning, internet-based learning, web- based instruction, cyber learning, virtual learning, or network-based learning. Urdan \& Weggen (2000) clarified that online learning is a subset of distance learning and embraces a wide range of technologies, applications and learning processes, including computer-based learning, web-based learning, virtual learning, and digital collaborations.

Online learning relies not only on online contexts, but also encompasses a wide range of computer-based educational tools and delivery mechanisms, genres, formats, and media such as multimedia, instructional programming, simulations, gaming, and the use of new media on fixed and mobile platforms in all disciplines. Campbell (2004) argues that the focus of online learning in higher education settings is on the creation of metacognitive, analytical, and interactive learning. In addition, online learning goes beyond the expected subject learning to consider the importance of the unplanned and self- 
directed learner to optimize incidental learning and enhance results.

In a comparative analysis, Dabbagh and NannaRitland (2005) explored the discrepancies between conventional and online learning environments and argued that traditional learning environments are bound by a) the position and presence of the teacher and student; (b) portrayed in real time; (c) regulated by the instructor; and (d) linear in teaching methods. The use of emerging knowledge and communication technology, asynchronous communication and real-time information, online teaching and learning environments are unbound and complex. Online learning environments provide several pedagogical methods and are often distinguished by active student-centered teaching approaches (Baker, 2003).

Online learning appeals to a significant number of students because it provides versatility in participation, ease of access and convenience. Furthermore, online learning is anticipated to expand to play a significant role in higher learning. In a recent study on the state of online learning in the United States, Allen and Seaman (2013) revealed that over 6.7 million students took at least one online course in the fall of 2012, accounting for $32 \%$ of all higher education students. This figure reflects a rise of more than 570,000 students over the previous year a growth rate of 9.3 per cent for online enrolment that significantly exceeds the growth rate of less than 2 per cent of the higher education student population. Online learning within higher education institutions therefore requires the immediate attention of strategic university planners, faculty members and students.

Online learning appeals to a significant number of students because it provides versatility in participation, ease of access and convenience. Furthermore, online learning is projected to continue to play a significant role in higher learning. In a recent study on the state of online learning in the United States, Allen and
Seaman (2013) estimated that over 6.7 million students took at least one online course in the fall of 2012, accounting for $32 \%$ of all higher education students. This number is an improvement of the more than 570,000 students registered in the previous year, 9.3 per cent growth in online enrolment far exceeds less than 2 per cent growth in the higher education student population. Online learning within higher education institutions therefore requires the immediate attention of strategic university planners, faculty members and students.

Online learning, on the other hand, may pose severe problem with signal strength, incompatible devices and plagiarism (Arkorful \& Abaidoo, 2015). This transformation poses several issues, considering its practicality. The lecturer may have no knowledge of using an online application. Similarly, lack of hardware and software, poor internet connectivity, procrastination of learners, lack of technological knowledge among teachers, lack of orientation for learners, and lack of release time, the lecturer abilityto create and design their online courses have been cited as obstacles to faculty involvement in the creation and teaching of online courses (Nkonge \& Gueldenzoph, 2006). The researchers have suggested instruction and resources for teachers. Faculty support is significant due to the number of faculty members who begin online teaching experience with little knowledge of the process of planning, creating, and teaching an online course (Cuellar, 2002)

Several online learning research studies (Fauzi \& Sastra Khusuma, 2020) (Fauzi \& Sastra Khusuma, 2020) (Hoq, 2020) have been conducted in the area of the implementation of online education (Irfan et al., 2020). Most research in higher education and tertiary education however has been undertaken. This research has been carried out teacher education.

This research concentrated on five components: 1) online applications frequently applied by faculty members; 2) 
online learning activities frequently conducted out by faculty members; 3 ) submission rates; 4) student participation; and 5) online learning challenges for doctors; and alternative solutions proposed by lecturers.

The findings of this study are expected to expand our insights into the implementation of online learning, particularly in teacher higher education, and also enable teacher higher education administrators to develop best practice in teacher higher education. The researcher also expected that the results will be followed by other researchers to formulate best practice for the implementation of online learning, particularly in higher education.

\section{RESEARCH METHOD}

A qualitative methodology was employed in this research. The methodology used is method of survey. The participants in this study were 8 lecturers from English Department of STKIP Al Hikmah Surabaya who taught during the 2019/2020 semester of the academic year. The only instrument used in this analysis was a regular online teaching reporting and assessment questionnaire. It is made up of 13 objects

The questionnaire was rendered in google form, consisting of both open and closed objects, so that the lecturers could easily access it and fill it out after teaching his or her lesson. The data analysis in this study was performed based on an inductive content analysis. Mayring (2015) clarified that content analysis produce response categories based on the free response that was sent by the respondent.

This content analysis requires (a) open coding, at this point by the researcher provides notes of the different responses that come from the respondent (b) make categorization, the researchers group by making categorization based on the themes/categories that arise, and (c) make an abstraction, at this point, the researcher shall make a general definition based on the categories that have been defined. After the content analysis process is completed, the response is measured using descriptive statistics and the results are analyzed in depth, (2) The closed questionnaire shall be computed using descriptive statistics and the results shall be evaluated in depth.

\section{FINDINGS AND DISCUSSION}

The teaching monitoring and evaluation questionnaire was submitted and completed by the lecturers at the end of the academic year 2019/2020 during the same semester. The results of this study are divided into five aspects, namely: 1) online learning applications often used by lecturers; 2) online learning activities often conducted by lecturers; 3 ) assignment submission rate; 4) student participation rate; and 5) challenges/difficulties faced by lecturers during online learning.

1) Online learning applications frequently used by the lecturers.

WhatsApp (93 per cent), Google Classroom (61 per cent), Schoology (39 per cent), Quizzes (34 per cent), Email (27 per cent) Zoom Cloud Meeting (20.7 per cent) and Youtube ( 2 per cent) are subsequently the most frequently used online learning framework or so-called learning management system (LMS). WhatsApp is the most frequent program of online learning (Widiyono, 2020). In addition, it is clarified that WhatsApp enables direct interaction between teachers and students, enabling students to continue learning outside the classroom (Salem M. Alqahtani et al., 2018). Furthermore, its features empower students to interact and correspond in any language and person in the world. Moreover, WhatsApp is claimed to be more data-friendly and student friendly 
(Eko Yulianto et al., 2020). More detailed information on online learning applications or the so-called learning management system (LMS) is shown in the following chart.

The most frequent learning management system used during online learning

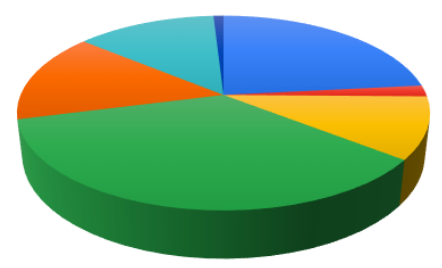

- Google Classroom = Zoom Cloud Meeting $=$ E-mail

-WhatsApp $\quad$-Schoology $\quad$ Quizziz

- Youtube

Figure 1. Online Learning Applications Most Frequently used by Lecturers

2) Online learning practices often performed by lecturers

The most frequent online learning practice performed by lecturers is uploading materials ( 88 per cent). The next learning activity is discussion forum (80 per cent), uploading material $(67 \%)$, conducting quizzes (66 per cent), uploading scheduled assignment (59 per cent) and video conferences ( 7 per cent) and more. More detailed information on the online learning tasks mostly undertaken by lecturers can be found on the following chart.

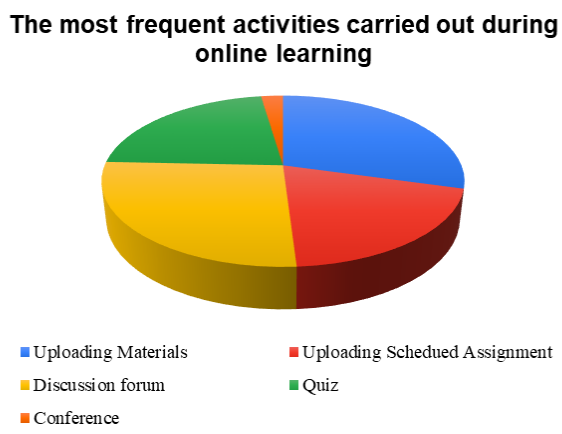

Figure 2. Online Learning Activities Frequently conducted by the Lecturers
3) Task submission rate

Structured assignments or portfolios are delivered during online learning. The rate of submission of punctual scheduled tasks or portfolios was 43.9 per cent. The rate was not quite sufficient. Various issues have contributed to this finding. The most significant contributing factors to this result would be the network problem and incompatible device. In addition, the absence of an internet signal has become the most critical factor in the online learning process (Riyanda et al., 2020).

4) Participation rate of students during the implementation of online learning Participation could be a major problem in online learning. Participation of students during online learning during the Covid-19 pandemic reached $43.4 \%$. The rate was not satisfactory. The major cause of low student participation is the internet signal. It is confirmed that bad internet signals have serious impact on student learning time (Ernawati et al., 2020) .

5) The difficulties faced by lecturers during online learning

The difficulties faced by lecturers during online learning are 1) internet network (49 per cent). Student condition becomes the next challenges occurred during online learning. The subsequent challenge is incompatible devices. More detailed information can be seen in the following chart.

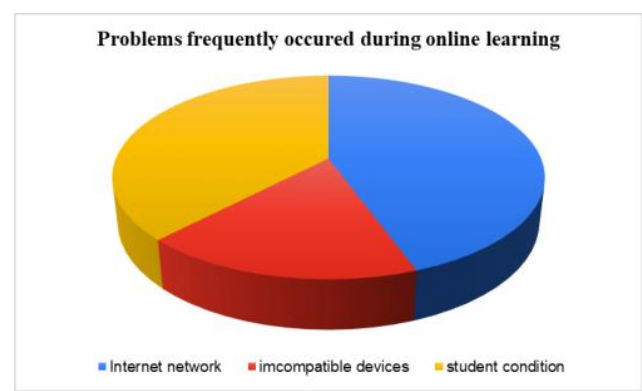

Figure 3. Challenges experienced by the lecturers during the online learning 
Henceforth, the potential solutions to such problems are represented as follows: 1) prior information in WAG, advisory coordination, contacting absented students, 2) providing hard copied materials, 3 ) providing alternative accessible learning platforms, and 4) changing the internet provider.

Alternative solutions proposed during online learning

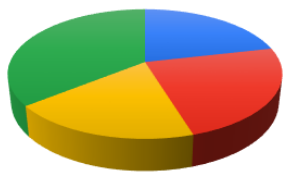

- providing alternative platforms

- providing hard copied materials/alternative materials

minforming through WhatsApp Group

- Others (prior informing, coordinating with advisor, contacting students and

Figure 4. Alternative Solution conducted by the Lecturers during the Online Learning

\section{CONCLUSION AND SUGGESTION}

This section discusses the conclusion of the research and suggestion.

\section{Conclusion}

Based on the data presentation and research findings and discussion, it can be elaborated that the most frequently used online learning application or so-called learning management system (LMS) are WhatsApp (93 per cent), Google Classroom (61 per cent), Schoology (39 per cent), Quizziz (34 per cent), Email (27 per cent) Zoom Cloud Meeting (20.7 per cent) and Youtube (2 per cent). Online learning practices frequently performed by lecturers involve uploading materials (88 per cent). The next learning activity is discussion forum (80 per cent), uploading material (67\%), conducting quizzes (66 per cent), uploading scheduled assignment (59 per cent) and video conferences ( 7 per cent). The rate of submission of punctual scheduled tasks or portfolios reached 43.9 per cent. Participation of students during online learning during the Covid-19 pandemic was 43.4 per cent

The problems faced by lecturers during online learning are internet network (49 per cent). Student condition becomes the next challenges occurred during online learning. The subsequent challenge is incompatible devices. The potential solutions to such problems are represented as follows: 1) prior information in WAG, advisory coordination, contacting absented students, 2) providing hard copied materials, 3) providing alternative accessible learning platforms, and 4) changing the internet provider.

\section{REFERENCES}

Allen, I. E., \& Seaman, J. (2013). Changing course: Ten years of tracking online education in the United States. Sloan Consortium. PO Box 1238, Newburyport, MA 01950.

Allo, M. D. G. (2020). Is the online learning good in the midst of Covid19 Pandemic? The case of EFL learners. Jurnal Sinestesia, 10(1), 110. 
Arkorful, V., \& Abaidoo, N. (2015). The role of e-learning, advantages and disadvantages of its adoption in higher education. International Journal of Instructional Technology and Distance Learning, 12(1), 2942.

Baker, A. (2003). Faculty development for teaching online: Educational and technological issues. The Journal of Continuing Education in Nursing, 34(6), 273-278.

Campbell, J. L. (2004). Institutional change and globalization. Princeton University Press.

Dabbagh. N., \& NannaRitland, B. (2005). Online learning: Concepts, strategies and application. New Jersey, NJ: Upper Saddle River.

Eko Yulianto, Putri Dwi Cahyani, \& Sofia Silvianita. (2020). Perbandingan Kehadiran Sosial dalam Pembelajaran Daring Menggunakan Whatsapp groupdan Webinar Zoom Berdasarkan Sudut Pandang Pembelajar Pada Masa Pandemic COVID-19. JARTIKA Jurnal Riset Teknologi Dan Inovasi Pendidikan, 3(2), 331-341. https://doi.org/10.36765/jartika.v3i2. 277

Ernawati, Y., Universitas, D., \& Darma, B. (2020). Problematik Pembelajaran Daring. 13(1), 1-15.

Fauzi, I., \& Sastra Khusuma, I. H. (2020). Teachers' Elementary School in Online Learning of COVID-19 Pandemic Conditions. Jurnal Iqra': Kajian Ilmu Pendidikan, 5(1), 5870.https://doi.org/10.25217/ji.v5i1.9 14

Hoq, M. Z. (2020). E-Learning During the Period of Pandemic (COVID-19) in the Kingdom of Saudi Arabia: An Empirical Study. American Journal of Educational Research, 8(7), 457464.https://doi.org/10.12691/educati on-8-7-2

Irfan, M., Kusumaningrum, B., Yulia, Y., \& Widodo, S. A. (2020). Challenges During the Pandemic: Use of ELearning in Mathematics Learning in Higher Education. Infinity Journal, 9(2), 147. https://doi.org/10.22460/infinity.v9i2 .p147-158

Johnson, H. P., \& Mejia, M. C. (2014). Online learning and student outcomes in California's community colleges. Public Policy Institute.

Nkonge, B., \& Gueldenzoph, L. E. (2006). Best practices in online education: Implications for policy and practice. Business Education Digest, (15).

Riyanda, A. R., Herlina, K., \& Wicaksono, B. A. (2020). Evaluasi Implementasi Sistem Pembelajaran Daring Fakultas Keguruan dan Ilmu Pendidikan Universitas Lampung. Jurnal IKRA-ITH Humaniora, 4(1), 66-71. https://journals.upiyai.ac.id/index.php/ikraithhumaniora/article/view/669

Salem M. Alqahtani, M., Bhaskar, C. V., Vadakalur Elumalai, K., \& Abumelha, M. (2018). WhatsApp: An Online Platform for UniversityLevel English Language Education. Arab World English Journal, 9(4), 108-121.

https://doi.org/10.24093/awej/vol9no 4.7

Urdan, T. A., \& Weggen, C. C. (2000). Corporate elearning: Exploring a new frontier. 
Widiyono, A. (2020). Efektifitas Perkuliahan Daring (Online) pada Mahasiswa PGSD di Saat Pandemi Covid 19. Jurnal Pendidikan, 8(2), 169-177.

https://doi.org/10.36232/pendidikan. v8i2.458 